\title{
Fibre pits in wood of Xylopia emarginata Mart. (Annonaceae), Reserva Biológica e Estação Ecológica de Mogi-Guaçu, São Paulo State, Brazil
}

\author{
Agnes E. Luchi ${ }^{1}$
}

Received: 1.08.2016; accepted: 23.08.2016

\begin{abstract}
Fibre pits in wood of Xylopia emarginata Mart. (Annonaceae), Reserva Biológica e Estação Ecológica de MogiGuaçu, São Paulo State, Brazil). The influence of environmental conditions such as flooding areas on the anatomical features of wood is little known. The aim of this study was to compare the fibre pits in the stems and in the roots of Xylopia emarginata growing in a swampy forest and in a Brazilian savanna (Cerrado). Samples of stems and roots of $X$. emarginata were collected in the Mogi-Guaçu Biological Reserve and Experimental Station using a non-destructive method. Our anatomical study of the wood included analyses in two sectional planes (radial and tangential sections). Quantitative data of the fibre pits were processed using the Sample Size Estimator Worksheet software to obtain the statistical parameters, and BioEstat 2.0 was used to perform a non-parametric Mann-Whitney test. Analyses by scanning electron microscopy showed large differences in the number of fibre pits between stem and root in samples from the swampy forest and the Cerrado. The largest number of pits occurred in the radial walls of the fibres; there were at least twice as many pits in the roots as in the stems of specimens from both the swampy forest and the cerrado.
\end{abstract}

Keywords: cerrado, flooding soil, root, stem, wood anatomy

RESUMO - (Pontoações de fibras no lenho de Xylopia emarginata Mart. (Annonaceae), Reserva Biológica e Estação Ecológica de Mogi-Guaçu, SP, Brasil). A influência das condições ambientais tais como áreas de inundação sobre as características anatômicas da madeira é pouco conhecido. O objetivo deste trabalho foi comparar as pontoações das fibras do caule e raiz de Xylopia emarginata da mata de brejo e cerrado. Amostras de madeira do caule e raiz de X. emarginata foram coletadas na Reserva Biológica e Estação Experimental de Moji-Guaçu usando método não-destrutivo. O estudo anatômico do lenho incluiu análises em dois planos seccionais (secções tangenciais e radiais). Os dados quantitativos das pontoações de fibra foram processados usando a planilha Size Estimator software amostra para obter os parâmetros estatísticos, e BioEstat 2.0 para executar teste não paramétrico de Mann-Whitney. Análises por microscopia eletrônica de varredura mostrou grande diferença no número de pontoações das fibras entre caule e raiz de floresta paludosa e de cerrado. O maior número de pontoações ocorre nas paredes radiais das fibras, sendo que as raízes apresentam o dobro do número de pontoações que os caules tanto para os espécimes de mata de brejo quanto para os de cerrado.

Palavras-chave : anatomia de madeira, caule, cerrado, mata de brejo, raiz

\section{Introduction}

Xylopia emarginata Mart. (Annonaceae) is a species characteristic of swamp forest, and does not grow in the driest places (Torres et al. 1992); it presents heights ranging from 10 to 20 meters, with trunk reaching diameters of no more than 30 to 40 $\mathrm{cm}$. It usually grows in large clusters, forming a homogeneous mass (Jaeger et al. 2007).

Although it is well known that environmental factors have a sizeable influence on the anatomical characteristics of wood (Carlquist 1975, Baas \& Schweingruber 1987, Luchi 2004 Sonsin et al. 2012), studies on the structural characteristics of wood which enable the survival of a tree species in naturally flooded areas are still scarce as well as studies that compare the stem and roots of the same species.

In preliminary analysis about the ecological anatomy of Xylopia emarginata specimens from wetland environments, I noticed that this species showed large differences in the number of fibre pits when comparing the stem to the root.

This paper intends to verify statistically the quantitative difference between the pits in the fibres of the stems and roots of the Xylopia emarginata, and the possible environmental interference in the quantitative number of fibre pits found in each. To verify that possible environmental interference, samples growing in Cerrado, because animals disperse its fruits and seeds outside of its typical habitat, were also analysed.

1. Instituto de Botânica, Núcleo de Pesquisa em Anatomia, Caixa Postal 68041, 04045-972 São Paulo, SP, Brasil

2. Corresponding author: aeluchi@ibot.sp.gov.br 


\section{Material and methods}

Wood samples of the stem and root were collected from two distinct populations, a forest swamp and a typical Brazilian savanna (Cerrado), both found in the Reserva Biológica e Estação Ecológica de

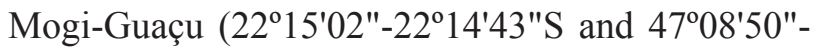
$47^{\circ} 07^{\prime} 60^{\prime \prime} \mathrm{W}$ ), which is located in the Martinho Prado Junior district in Mogi-Guaçu, São Paulo State, Brazil. The samples were collected using a non-destructive method (Luchi 2005).

Stem samples were collected $1.30 \mathrm{~m}$ from the ground, using saw, chisel and hammer; root samples were collected about $50 \mathrm{~cm}$ deep in the soil, with the help of a saw. Woody samples of the stem and root were taken from the same specimen (table 1).

The samples were deposited at Xylarium (SPw) of the Herbarium "Maria Eneida P. Kauffmann Fidalgo", Instituto de Botânica, São Paulo, São Paulo State, Brazil.

As Annonaceae is known for presenting fibre pits in the radial wall as well as well the tangential wall (Metcalfe 1987), both walls were analyzed.

For the scanning electron microscopy study (SEM), wood samples of stem and root were taken in radial and tangential sections ( $20 \mu \mathrm{m}$ thick in sliding microtome), dehydrated and coated with a gold layer.

The pits were quantitatively analyzed by measuring the tangential and radial sections of the fibres walls in $100 \mu \mathrm{m}^{2}(\mathrm{n}=20)$ for each sample.

The quantitative data was processed to obtain statistical parameters and to do the nonparametric Kruskal-Wallis test.

\section{Results}

Quantitative data (average \pm standard deviation; minimum and maximum values) of fibre pits of Xylopia emarginata are presented in table 2.

It is observed that for radial walls, there were no significant differences in the number of fibres pits when comparing stem/stem and root/root from swamp forest and cerrado specimens. However, statistically significant differences were seen between the stems and roots from both environments (table 2, figures $1-4)$.

For tangential walls, there were also no significant differences in the number of fibre pits in the stems from both environments (table 2, figures 5 and 7). However, a significant difference existed in the number of pits in the roots of the specimens from both the swamp forest and the cerrado (table 2, figures 6 and 8) when compared to the stem. The highest number of pits occurred on the roots of the swamp forest specimens (table 2). When we compared the pits in the tangential walls of the stems and the roots, we found significant quantitative differences between the two environments (table 2).

\section{Discussion}

The data presented makes clear that, independent of the specimen's environment, there exist differences in the number of fibres pits when comparing stems and their roots.

When looking at the radial wall the average number of pits in the roots is twice that found in the stems, this is true for both environments (swamp forest and cerrado); in the tangential wall the number of pits is four (cerrado) or six (swamp forest) times larger. It is worth noting that in the tangential walls the size of the pits was four to five times smaller than that of those found in the radial walls.

Metcalf \& Chalk (1950), speaking of the Annonaceae, described: "fibres with small, but often distinctly bordered pits, which are equally numerous on radial and tangential walls".

Also in regards to the Annonaceae, Metcalfe (1987) demonstrated that: "fibres usually with numerous simple or narrowly bordered pits in both the radial and tangential walls", and, in 2012, Koek-Noorman \& Westra, reported: "Pits (in fibres) are mostly small, simple or with narrow borders, numerous on radial and tangential walls"

These conclusions are understandable because, as of yet, the number of fibre pits is a feature not fully quantified in the literature, especially in regards to possible differences between the stem and root of the species.

Emphasizing that the aforementioned literature is restricted to the stems, our data verifies significant quantitative differences between the pits as seen in the radial walls in contrast to the tangential walls of the stems and roots.

In regards to the tangential walls, although the roots show a much higher number of pits than that found in the stems, they show much lower numbers than those observed in the radial walls.

Conditions of higher water availability affects ontogenetic characteristics in respect to the size of the plant cell (Levit 1980); the soil of these two environments has significant water features: the 
Table 1. Data of samples of Xylopia emarginata Mart. SPw: Herbarium.

\begin{tabular}{lcccc}
\hline Area & SPw & $\begin{array}{c}\text { heigth } \\
(\mathrm{m})\end{array}$ & $\begin{array}{c}\text { trunk diameter } \\
(\mathrm{cm})\end{array}$ & $\begin{array}{c}\text { root diameter } \\
(\mathrm{cm})\end{array}$ \\
\hline & 1856 & 10 & 14.30 & $3.00 \times 2.50$ \\
Swamp forest & 1857 & 10 & 15.10 & $3.00 \times 2.00$ \\
& 1858 & 10 & 13.40 & $5.00 \times 3.00$ \\
"Cerrado" & 1913 & 7 & 6.40 & $3.00 \times 3.50$ \\
& 1935 & 8 & 11.00 & $6.00 \times 4.50$ \\
\hline
\end{tabular}

Table 2. Fibre pits quantitative data in Xylopia emarginata Mart. Average \pm standard deviation, minimum and maximum values in parentheses.

\begin{tabular}{lcccc}
\hline & \multicolumn{2}{c}{ Radial longitudinal section } & \multicolumn{2}{c}{ Tangential longitudinal section } \\
\hline \multirow{2}{*}{ Swamp forest } & "Cerrado" & Swamp forest & "Cerrado" \\
Stem & $32(17-45) \pm 8 \mathrm{a}^{*}, b$ & $27(14-49) \pm 9 \mathrm{a}, b$ & $7(0-20) \pm 5 \mathrm{~A}, b$ & $5(0-12) \pm 4 \mathrm{~A}, b$ \\
Root & $66(39-94) \pm 13 \mathrm{a}, a$ & $58(35-80) \pm 13 \mathrm{a}, a$ & $46(33-65) \pm 9 \mathrm{~A}, a$ & $23(10-33) \pm 7 \mathrm{~B}, a$ \\
\hline
\end{tabular}

* lowercase and uppercase letters equal on the same line do not differ statistically between itself, different letters in italic on the same column differ between organs.

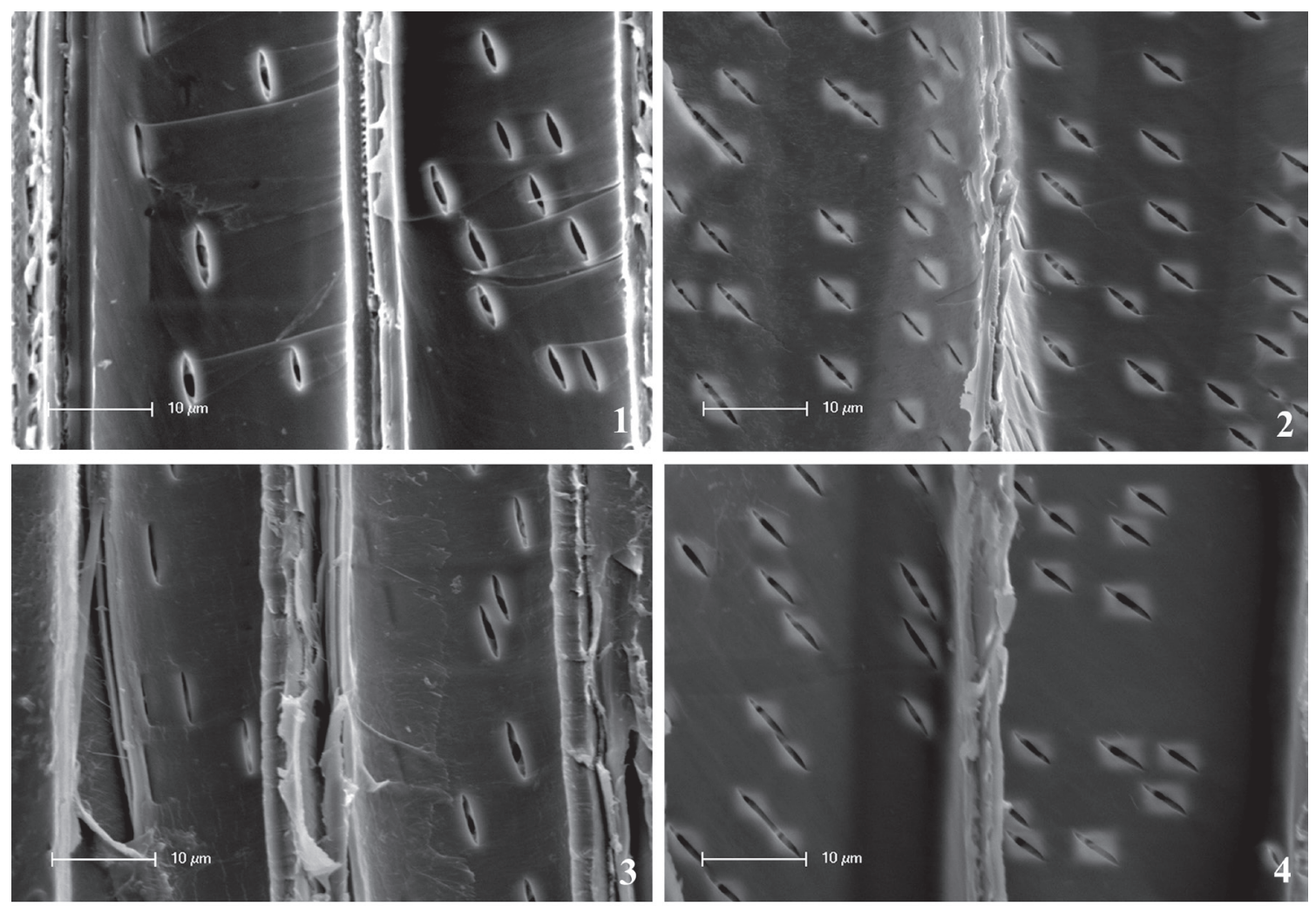

Figures 1-4. SEM micrographs of fiber pits (radial walls) of Xylopia emarginata. 1-2. Swampy forest specimen. 1. Stem. 2. Root. 3-4. Cerrado specimen. 3. Stem. 4. Root. 

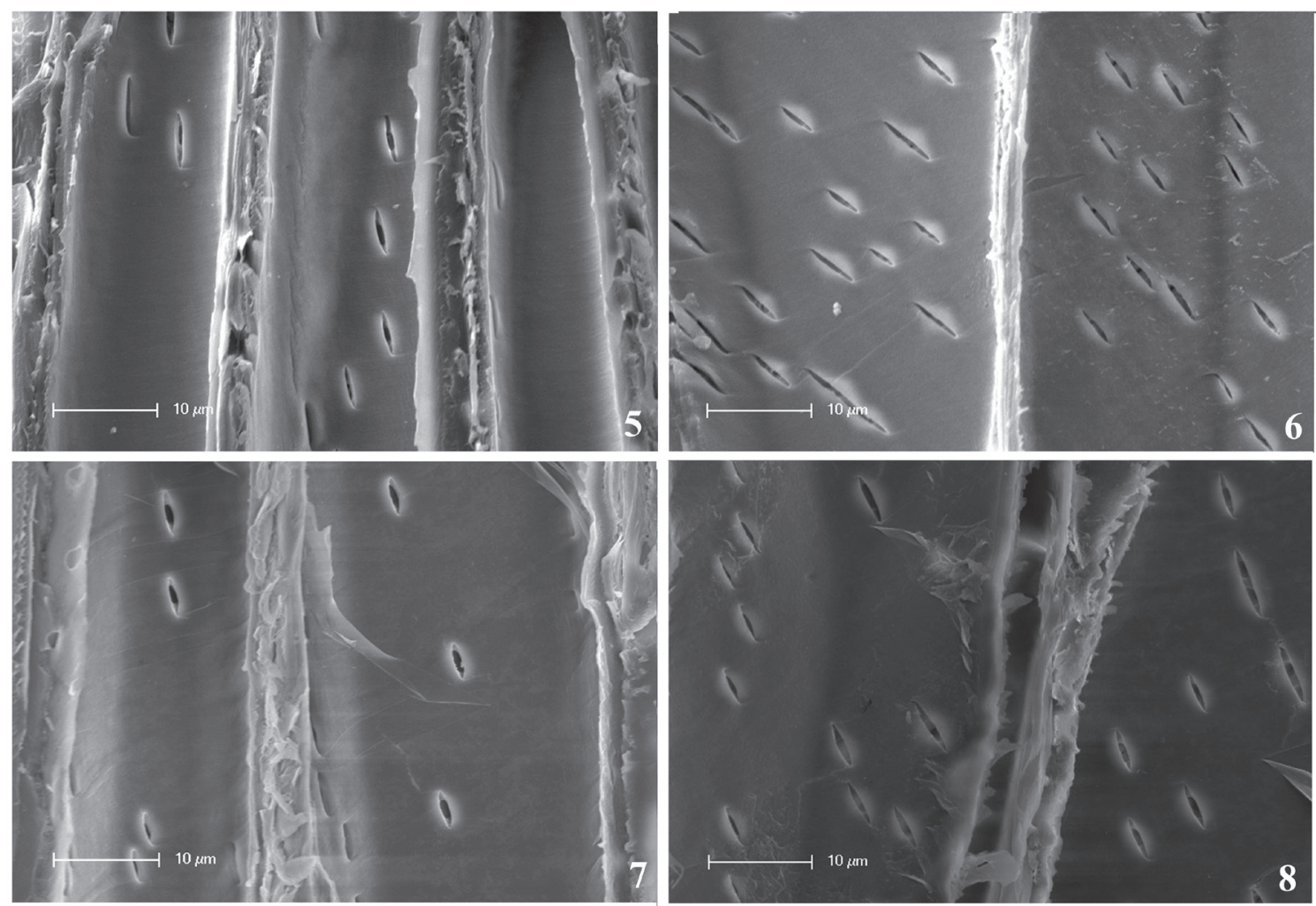

Figures 5-8. SEM micrographs of fiber pits (tangential walls) of Xylopia emarginata. 5-6. Swampy forest specimen. 5. Stem. 6. Root. 7-8. Cerrado specimen. 7. Stem. 8. Root.

cerrado experiences a long period of annual water deficit, and the soil of the swamp forest is constantly being flooded.These diferences would cause one to expect differences in the number of fibre pits in both organs, when comparing the two environments, rather than only in the roots as this paper shows.

Given the results of this paper, it seems clear that further research in this area, is necessary.

\section{Literature cited}

Baas, P. \& Schweingruber, F.H. 1987. Ecological trends in the wood anatomy of trees, shrubs and climbers from Europe. IAWA Bulletin new series 8: 245-274.

Carlquist, S. 1975. Ecological strategies in xylem evolution. University of California Press, Berkeley.

Jaeger, P., Moura, M.C.O., Van Der Berg, E. \& Carvalho, D. 2007. Caracterização genética de populações naturais de Xylopia emarginata Mart. (Annonaceae). Scientia Forestalis 73: 91-99.

Koek-Noorman, J. \& Westra, L.Y.T. 2012. Macrophotographic wood atlas of Annonaceae. Botanical Journal of the Linnean Society, 169: 135-189.
Levit, J. 1980. Responses of plants to environmental stress. V. I - Chilling, freezing and high temperature stresses. Physiological Ecology. Academic Press. New York.

Luchi, A.E. 2004. Anatomia do lenho de Croton urucurana Baill. (Euphorbiaceae) de solos com diferentes níveis de umidade. Revista Brasileira de Botânica, 27: 271-280.

Luchi, A.E., Silva, L.C.P. \& Moraes, M.A. 2005. Anatomia comparada do lenho de Xylopia aromatica (Lam.) Mart. Em áreas de cerrado e de plantação de Pinus elliottii Engelm.. Revista Brasisleira de Botânica 28:809-920.

Metcalf, C.R. \& Chalk, L. 1950. Anatomy of the dicotyledons. v. I. Clarendon Press. Oxford.

Metcalfe, C.R. 1987. Anatomy of the dicotiledons. 2 ed. v. III. Magnoliales, Illiciales and Laurales. Clarendon Press. Oxford.

Sonsin, J.O., Gasson, P.E. Barros, C.F., \& Marcati, C.R. 2012. A comparison of the wood anatomy of 11 species, from two cerrado hatitats (cerrado s.s. and adjacent gallery forest). Botanical Journal of the Linnean Society, 170: 257-276.

Torres, R.B., Matthes, L.A.F., Rodrigues, R.R. \& Leitão Filho, H.F. 1992. Espécies florestais nativas para plantio em áreas de brejo. O Agronômico. 44: 13-16. 